\title{
Adiponectin and Resistin Gene Polymorphisms in Patients with Anorexia Nervosa and Obesity and Its Influence on Metabolic Phenotype
}

\author{
J. KŘÍŽOVÁ ${ }^{1}$, M. DOLINKOVÁ ${ }^{1}$, Z. LACINOVÁ ${ }^{1}$, Š. SULEK $^{1}$, R. DOLEŽALOVÁ ${ }^{1}$, \\ J. HOUSOVÁ ${ }^{1}$, J. KRAJÍČKOVÁ ${ }^{1}$, D. HALUZÍKOVÁ ${ }^{1,2}$, L. BOŠANSKÁ ${ }^{1}$, H. PAPEŽOVÁ ${ }^{3}$, \\ M. HALUZÍK ${ }^{1}$
}

${ }^{1}$ Third Department of Medicine, ${ }^{2}$ Department of Sports Medicine and ${ }^{3}$ Department of Psychiatry, First Medical Faculty, Charles University, Prague, Czech Republic

Received January 17, 2007

Accepted June 1, 2007

On-line July 26, 2007

\begin{abstract}
Summary
Genes for adiponectin and resistin are candidate genes of insulin resistance and type 2 diabetes mellitus. The aim of our study was to determine the frequency of single nucleotide polymorphisms (SNP) $45 \mathrm{~T}>\mathrm{G}$ and $276 \mathrm{G}>\mathrm{T}$ of the adiponectin gene and $62 \mathrm{G}>\mathrm{A}$ and $-180 C>G$ of the resistin gene in patients with obesity $(O B)$, anorexia nervosa (AN) and in control healthy normal-weight women (NW) and to study the influence of particular genotypes on serum concentrations of these hormones and on insulin sensitivity. Serum adiponectin, resistin, tumor necrosis factor alpha (TNF-alpha), insulin, cholesterol, glycated hemoglobin (HbA1c) and blood glucose levels were measured in 77 patients with $\mathrm{OB}, 28$ with $\mathrm{AN}$ and $38 \mathrm{NW}$. DNA analysis was carried out by polymerase chain reaction with restriction analysis of $P C R$ product. The presence of SNP ADP+276 G>T allele was accompanied by higher cholesterol levels in AN patients, higher adiponectin concentrations in $\mathrm{OB}$ patients and lower $\mathrm{HbA1c}$ levels in NW. SNP of the resistin gene $62 \mathrm{G}>\mathrm{A}$ was associated with lower HbA1c in NW and higher cholesterol concentrations in $\mathrm{OB}$ group. The carriers of the minor $\mathrm{G}$ allele in the position -180 of the resistin gene within AN group had significantly higher BMI relative to non-carriers. We conclude that polymorphisms in adiponectin and resistin genes can contribute to metabolic phenotype of patients with obesity and anorexia nervosa.
\end{abstract}

\section{Key words}

Adiponectin • Resistin • Polymorphism • Obesity • Anorexia Nervosa

\section{Corresponding author}

M. Haluzík, Third Department of Medicine, First Medical Faculty, Charles University, U Nemocnice 1, 12808 Prague 2, Czech Republic. E-mail: mhalu@lf1.cuni.cz

\section{Introduction}

Adipose tissue is now considered an important endocrine organ that produces numerous factors affecting food intake, metabolism of lipids and carbohydrates and numerous other processes in human body (Havel 2002). Some of adipose tissue-derived hormones such as adiponectin and resistin can represent a possible connection between obesity and insulin resistance (Haluzík et al. 2004b, Steppan et al. 2001). Adiponectin (ADP) is a protein hormone produced almost exclusively in adipose tissue (Scherer et al. 1995). It is considered one of the few insulin-sensitizing factors produced by adipose tissue. Its circulating levels are decreased in patients with obesity and type 2 diabetes (Arita et al. 1999, Hotta et al. 2000). Furthermore, it has been demonstrated that patients with reduced adipose tissue mass (e.g. patients with anorexia nervosa or endurancetrained sportsmen) have markedly increased adiponectin circulating levels (Haluzík et al. 1999, Delporte et al. 2003, Housová et al. 2005). Recombinant adiponectin treatment decreases blood glucose in normal and diabetic rats predominantly due to increased liver insulin sensitivity (Berg et al. 2001). Mice with the knock-out of the adiponectin gene are characterized by insulin resistance and accelerated atherosclerosis which are both normalized by recombinant adiponectin substitution (Kubota et al. 2002).

Resistin (RETN) is a protein hormone produced both by adipocytes and immunocompetent cells including 
those residing in adipose tissue. Some studies found increased circulating resistin levels and its mRNA expression in adipose tissue in patients with obesity (Degawa-Yamauchi et al. 2003) while other studies failed to confirm this finding (Lee et al. 2003, Anderlová et al. 2006).

Circulating resistin levels are higher in genetic experimental models of obesity as well as in rodents with diet-induced obesity (Haluzík et al. 2004a). Resistin administration impairs glucose tolerance and insulin action, while its neutralization by anti-resistin antibody improves glucose tolerance and insulin sensitivity (Steppan et al. 2001). Furthermore, resistin mRNA expression decreases during starvation (Kim et al. 2001) and resistin administration stimulates glucose production in the liver as demonstrated in both normal and resistin knock-out mice (Rajala et al. 2003).

Despite some controversies both resistin and adiponectin genes are considered new candidate genes of insulin resistance and type 2 diabetes mellitus. Polymorphisms for both adiponectin and resistin genes have been studied in obese subjects and/or patients with type 2 diabetes, while to our best knowledge no data regarding single nucleotide polymorphisms in the adiponectin and the resistin genes in anorexia nervosa patients has been published yet.

The presence of $G$ allele in locus 276 of ADP gene was accompanied by lower and $\mathrm{T}$ allele by higher levels of ADP (Hara et al. 2002, Fredriksson et al. 2005). G/G genotype of SNP 276 was found to be associated with impaired glucose tolerance (Gonzalez-Sanchez et al. 2005). These authors also proved the connection between a presence of $\mathrm{G}$ allele in position 45 and impaired glucose tolerance. In contrast, the association between this polymorphism and insulin resistance was not described in another study (Filippi et al. 2004). Menzaghi et al. (2002) found out that genotypes $45 \mathrm{G}$ and $276 \mathrm{~T}$ of ADP gene tightly correlated with several markers of insulin resistance (body weight, waist circumference, HOMA index, total to HDL cholesterol ratio).

Two articles about resistin gene $62 \mathrm{G}>\mathrm{A}$ SNP were published. In Chinese population lower frequency of allele A was demonstrated in type 2 diabetic patients than in non-diabetic subjects. Diabetics with GG genotype had higher prevalence of arterial hypertension. Authors of this article consider this polymorphism an independent factor of type 2 diabetes mellitus and arterial hypertension (Tan et al. 2003). Similar study was presented by Gouni-Berthold et al. (2005) that did not prove the different frequency of allele A between diabetic and non-diabetic patients. Only one paper focused on $-180 \mathrm{C}>\mathrm{G}$ SNP in promotor region of resistin gene has been published so far. GG homozygotes had significantly higher levels of resistin mRNA in abdominal subcutaneous fat and these positively and independently correlated with insulin resistance and amount of fat in liver (Smith et al. 2003).

The aim of our study was to characterize the influence of polymorphisms $+45 \mathrm{~T}>\mathrm{G}$ and $+276 \mathrm{~T}>\mathrm{G}$ of the adiponectin gene and $+62 \mathrm{G}>\mathrm{A}$ and $-180 \mathrm{C}>\mathrm{G}$ of the resistin gene on the circulating levels of these hormones and metabolic phenotype of the carriers.

\section{Methods}

Twenty-eight female patients with anorexia nervosa (BMI $15.72 \pm 0.36 \mathrm{~kg} / \mathrm{m}^{2}$ ), 77 obese female patients (BMI $43.48 \pm 1.12 \mathrm{~kg} / \mathrm{m}^{2}$ ) and 38 age- and sexmatched healthy controls (BMI $22.32 \pm 0.40 \mathrm{~kg} / \mathrm{m}^{2}$ ) were included into the study. Control subjects had no family history of diabetes and/or obesity. The diagnosis of eating disorder was based on the Diagnostic Statistical Manual IV diagnostic system. All subjects provided written informed consent and the study was approved by the ethics review committee of the General University Hospital.

All subjects included into the study underwent a single blood drawing after overnight fasting and anthropometric examination (height and weight were taken, and body mass index (BMI) was calculated).

Serum adiponectin, resistin and TNF-alpha levels were measured by ELISA kits (Linco Research, USA, BioVendor, CR, R\&D Systems, USA) and insulin levels by RIA kit (Immunotech, CR). Serum glycated hemoglobin (HbA1c) concentrations were assessed by high performance liquid chromatography, serum cholesterol and blood glucose levels by standard laboratory methods at the Department of Clinical Biochemistry of the University Hospital in Prague. Homeostasis model assessment (HOMA) index was also calculated as described previously (Matthews et al. 1985).

DNA was isolated from $500 \mu \mathrm{l}$ of whole blood on the MagNA Pure Compact instrument using the MagNA Pure Nucleid Acid Isolation Kit (both Roche Diagnostics, GmbH, Germany). The average DNA concentration $(127.49 \pm 5.05 \mu \mathrm{g} / \mathrm{ml})$ was determined from absorbance at $260 \mathrm{~nm}$ (BioPhotometer, Eppendorf AG, 
Germany). All samples had a 260/280 nm absorbance ratio between 1.6 and 1.79. The integrity of the DNA was checked by electrophoresis on $0.8 \%$ agarose gel with an ethidium bromide.

Isolated DNA was used for determination of two single nucleotide polymorphisms (SNP) in the adiponectin gene (45 $\mathrm{T}>\mathrm{G}$ a $276 \mathrm{G}>\mathrm{T})$ and two SNP in the resistin gene $(62 \mathrm{G}>\mathrm{A},-180 \mathrm{C}>\mathrm{G})$.

All SNPs were detected by polymerase chain reaction (PCR) on the MyCycler ${ }^{\mathrm{TM}}$ Thermo Cycler instrument (Bio-Rad, USA) with subsequent restriction analysis of PCR products (RFLP).

The mix for all PCRs contained 2x PPP Master Mix (Top-Bio s.r.o., Czech Republic), forward and reverse primers, PCR $\mathrm{H}_{2} \mathrm{O}$ (Top-Bio s.r.o., Czech Republic) and approximately 150ng of DNA. All primer sequences as well as PCR and RFLP conditions are shown in Tables 1-4.

Table 1. Detection details of SNP adiponectin $45 \mathrm{~T}>\mathrm{G}$.

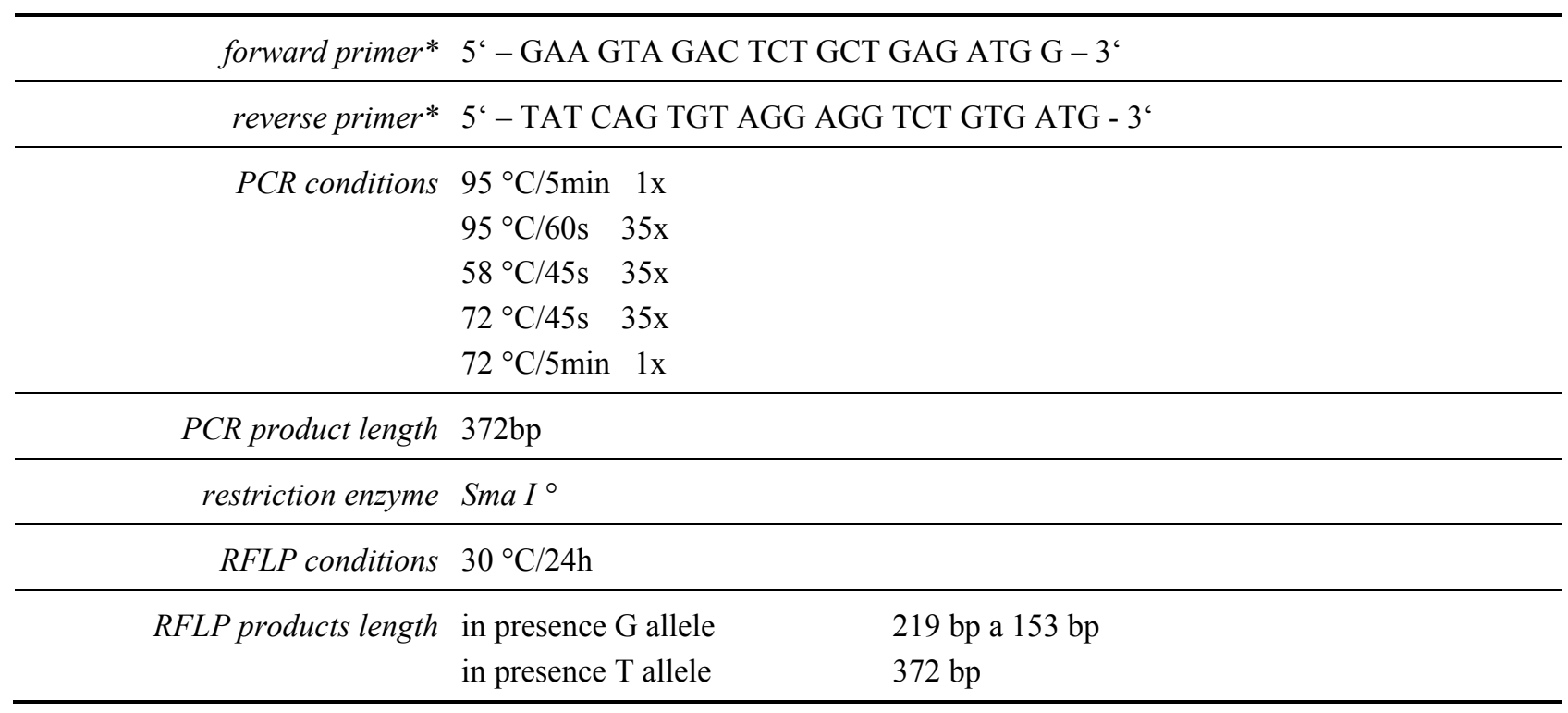

* primer sequences from (Xita et al. 2004)

- Fermentas Life Sciences, Lithuania

Table 2. Detection details of SNP adiponectin $276 \mathrm{G}>\mathrm{T}$.

\begin{tabular}{|c|c|}
\hline forward primer* & $5^{\star}$ - GGC CTC TTT CAT CAC AGA CC - 3“ \\
\hline reverse primer* & $5^{`}$ - AGA TGC AGC AAA GCC AAA GT - 3‘ \\
\hline \multirow[t]{5}{*}{ PCR conditions } & $95^{\circ} \mathrm{C} / 5 \min 1 \mathrm{x}$ \\
\hline & $95^{\circ} \mathrm{C} / 60 \mathrm{~s} \quad 35 \mathrm{x}$ \\
\hline & $58^{\circ} \mathrm{C} / 45 \mathrm{~s} \quad 35 \mathrm{x}$ \\
\hline & $72^{\circ} \mathrm{C} / 45 \mathrm{~s} \quad 35 \mathrm{x}$ \\
\hline & $72^{\circ} \mathrm{C} / 5 \min 1 \mathrm{x}$ \\
\hline PCR product length & 196 bp \\
\hline restriction enzyme & Mva $1269 I^{\circ}$ \\
\hline RFLP conditions & $37^{\circ} \mathrm{C} / 24 \mathrm{~h}$ \\
\hline RFLP products length & $\begin{array}{l}\text { in presence } \mathrm{G} \text { allele } 148 \mathrm{a} 48 \mathrm{bp} \\
\text { in presence T allele } 196 \mathrm{bp}\end{array}$ \\
\hline
\end{tabular}

* primer sequences from (Xita et al. 2004)

- Fermentas Life Sciences, Lithuania 
Table 3. Detection details of SNP resistin $+62 \mathrm{G}>\mathrm{A}$.

\begin{tabular}{|c|c|c|}
\hline forward primer* & $5^{\prime}-\mathrm{GCC}$ GAG ACC ACA TGT CAC T - $3^{\prime}$ & \\
\hline reverse primer* & $5^{`}$ - CCT CCG GGC CTA CTA AAG AA - $3^{‘}$ & \\
\hline \multirow[t]{5}{*}{ PCR conditions } & $96^{\circ} \mathrm{C} / 2 \min \quad 1 \mathrm{x}$ & \\
\hline & $94^{\circ} \mathrm{C} / 30 \mathrm{~s} \quad 35 \mathrm{x}$ & \\
\hline & $54,3^{\circ} \mathrm{C} / 30 \mathrm{~s} \quad 35 \mathrm{x}$ & \\
\hline & $72^{\circ} \mathrm{C} / 30 \mathrm{~s} \quad 35 \mathrm{x}$ & \\
\hline & $72^{\circ} \mathrm{C} / 5 \min \quad 1 \mathrm{x}$ & \\
\hline \multicolumn{3}{|c|}{ PCR product length 233 bp } \\
\hline \multicolumn{3}{|c|}{ restriction enzyme $B s e R I^{\circ}$} \\
\hline \multicolumn{3}{|c|}{ RFLP conditions $37^{\circ} \mathrm{C} / 24 \mathrm{~h}$} \\
\hline \multirow[t]{2}{*}{ RFLP products length } & in presence $A$ allele & 151 bp a 82 bp \\
\hline & in presence $\mathrm{T}$ allele & $233 \mathrm{bp}$ \\
\hline
\end{tabular}

* primer sequences from (Tan et al. 2003)

- New England Biolabs, USA

Table 4. Detection details of SNP resistin $-180 \mathrm{C}>\mathrm{G}$.

\begin{tabular}{|c|c|c|}
\hline forward primer* & $5^{`}$ - TTT TGT CAT GTT TGC ATC AGC - $3^{‘}$ & \\
\hline reverse primer* & $5^{`}$ - AGA TGC AGC AAA GCC AAA GT - 3“ & \\
\hline \multirow[t]{5}{*}{ PCR conditions } & $96^{\circ} \mathrm{C} / 2 \min 1 \mathrm{x}$ & \\
\hline & $94^{\circ} \mathrm{C} / 30 \mathrm{~s} \quad 35 \mathrm{x}$ & \\
\hline & $58,2^{\circ} \mathrm{C} / 30 \mathrm{~s} \quad 35 \mathrm{x}$ & \\
\hline & $72^{\circ} \mathrm{C} / 30 \mathrm{~s} \quad 35 \mathrm{x}$ & \\
\hline & $72^{\circ} \mathrm{C} / 5 \min \quad 1 \mathrm{x}$ & \\
\hline \multicolumn{3}{|c|}{ PCR product length $330 \mathrm{bp}$} \\
\hline \multicolumn{3}{|c|}{ restriction enzyme BpiI $^{\circ}$} \\
\hline \multicolumn{3}{|c|}{ RFLP conditions $37^{\circ} \mathrm{C} / 24 \mathrm{~h}$} \\
\hline \multirow[t]{2}{*}{ RFLP products length } & \multirow{2}{*}{$\begin{array}{l}\text { in presence } \mathrm{C} \text { allele } \\
\text { in presence } \mathrm{G} \text { allele }\end{array}$} & 202 bp a 128 bp \\
\hline & & $330 \mathrm{bp}$ \\
\hline
\end{tabular}

\footnotetext{
* primer sequences from (Smith et al. 2003)
}

- Fermentas Life Sciences, Lithuania

PCR and RFLP products were detected by electrophoresis on $2 \%$ agarose gel with $1 \%$ ethidium bromide. PCR and RFLP products were verified by sequence-based typing on the ABI PRISM 310 instrument (Applied Biosystems, Ca, USA).

Statistical analysis was performed using the SigmaStat software (Jandel Scientific, USA). Means and standard errors were calculated from obtained data. Significant differences between groups were confirmed by non-paired t-tests or Mann-Whitney Rank Sum tests. The differences in frequencies of individual polymorphisms were assessed by frequent analysis, Fisher exact tests and chi-square tests.

\section{Results}

Anthropometric, biochemical and hormonal parameters As expected BMI was markedly increased in 
Table 5. Body mass index (BMI), plasma concentrations of adiponectin, resistin, insulin, tumor necrosis factor-alpha (TNF- $\alpha$ ), cholesterol, glycated hemoglobin (HbA1c), blood glucose and HOMA index in patients with anorexia nervosa, obesity and in a control group of healthy normal-weight women.

\begin{tabular}{|c|c|c|c|}
\hline & Control group & Anorexia nervosa & Obese women \\
\hline$N$ & 38 & 28 & 77 \\
\hline$B M I\left(k g / m^{2}\right)$ & $22.32 \pm 0.40$ & $15.72 \pm 0.36^{* *++}$ & $43.48 \pm 1.12 * *$ о о \\
\hline Blood glucose (mmol/l) & $4.14 \pm 0.16$ & $3.91 \pm 0.05++$ & $5.65 \pm 0.23 * *$ о о \\
\hline Insulin $(m I U / l)$ & $15.52 \pm 1.87$ & $11.52 \pm 1.08++$ & $32.63 \pm 2.60 * *$ о о \\
\hline HOMA index (mmol.IU/l2) & $2.97 \pm 0.45$ & $2.00 \pm 0.18++$ & $8.65 \pm 0.85 * *$ о о \\
\hline $\operatorname{HbAlc}(\%)$ & $3.72 \pm 0.07$ & $3.41 \pm 0.12 *++$ & $4.21 \pm 0.12 *$ о о \\
\hline Cholesterol (mmol/l) & $4.86 \pm 0.14$ & $4.80 \pm 0.17$ & $4.88 \pm 0.11$ \\
\hline Adiponectin $(\mu g / m l)$ & $33.24 \pm 4.41$ & $58.44 \pm 7.17^{*++}$ & $17.02 \pm 1.19 * *$ O O \\
\hline Resistin $(n g / m l)$ & $6.27 \pm 0.50$ & $3.99 \pm 0.33^{*++}$ & $8.11 \pm 0.60 *$ о о \\
\hline TNF-alpha $(n g / m l)$ & $0.91 \pm 0.17$ & $1.37 \pm 0.30$ & $2.30 \pm 0.94$ \\
\hline
\end{tabular}

Results are expressed as means \pm S.E.M. * significant difference compared to a control group $(p<0.05)$, ** significant difference compared to a control group $(p<0.001),++$ significant difference compared to obese women $(p<0.001), \circ \circ$ significant difference compared to patients with anorexia nervosa $(p<0.001)$

obese and decreased in anorexia nervosa group relative to control group (Table 5). Blood glucose levels, insulin levels and HOMA index were significantly higher in obese group relative to both anorexia nervosa patients as well as control subjects. Glycated hemoglobin (HbA1c) concentrations were significantly higher in obese group relative to control subjects, while it was significantly lower in anorexia nervosa patients relative to both other groups. No differences in cholesterol levels were found between groups.

Adiponectin concentrations were significantly lower in obese women compared to the control group. In contrast, anorexia nervosa patients had significantly higher adiponectin levels compared to healthy women. Resistin concentrations were significantly higher in obese and lower in anorexia nervosa patients relative to control group. No differences in TNF- $\alpha$ serum concentrations were found between groups (Table 5).

Adiponectin and resistin gene polymorphism frequency and their influence on the metabolic phenotype

The frequency of studied genotypes did not differ between anorexia nervosa, obese and control group, respectively. Overall, the $\mathrm{G}$ allele in locus 62 and $\mathrm{C}$ allele in locus -180 of the resistin gene as well as the $\mathrm{T}$ allele in locus 45 and the $\mathrm{G}$ allele in locus 276 of the adiponectin gene were all present more frequently than minor alleles $A, G, G$ and $T$ in corresponding loci (RETN 62: $\mathrm{p}<0.0001$, RETN -180: $\mathrm{p}<0.0002$, ADP 45: $\mathrm{p}<0.0001$,
ADP 276: $p<0.0001)$. The frequency of $G$ allele in locus 62 of RETN gene was $94 \%$ in NW, $100 \%$ in AN and $96 \%$ in $\mathrm{OB}$, frequency of $\mathrm{C}$ allele in locus -180 of RETN gene was $81 \%$ in NW, $65 \%$ in $\mathrm{AN}$ and $65 \%$ in OB. T allele in position 45 od ADP gene was present in $95 \%$ of NW, $100 \%$ of AN and $94 \%$ of OB group and $\mathrm{G}$ allele in position 276 of ADP gene occurred in $83 \%$ of NW, $71 \%$ of AN and $72 \%$ of OB group (Table 6).

For further analysis, subjects in each group were divided into subgroups based on the genotype. In anorexia nervosa patients, serum cholesterol levels were higher in carriers of the minor $\mathrm{T}$ allele in position 276 of the adiponectin gene relative to $\mathrm{G} / \mathrm{G}$ genotype $(5.85 \pm 0.33$ vs. $4.56 \pm 0.20 \mathrm{mmol} / \mathrm{l}, \mathrm{p}<0.05)$. Furthermore, AN subjects with the minor $\mathrm{G}$ allele in position -180 of the resistin gene had higher BMI compared to carriers of the $\mathrm{C} / \mathrm{C}$ genotype (16.12 \pm 0.41 vs. $\left.14.54 \pm 0.59 \mathrm{~kg} / \mathrm{m}^{2}, \mathrm{p}<0.05\right)$.

In obese patients, carriers of the minor $\mathrm{T}$ allele had higher adiponectin levels than the $\mathrm{G} / \mathrm{G}$ homozygotes for $\mathrm{ADP}+276 \quad(18.95 \pm 1.94$ vs. $14.67 \pm 1.37 \mu \mathrm{g} / \mathrm{ml}$, $\mathrm{p}<0.05)$. Obese patients with the minor $A$ allele in position 62 of the resistin gene had higher cholesterol levels than $\mathrm{OB}$ patients with the $\mathrm{G} / \mathrm{G}$ genotype in the same position $(6.15 \pm 0.47$ vs. $4.77 \pm 0.44 \mathrm{mmol} / \mathrm{l}$, $\mathrm{p}<0.001)$.

In the control group, persons with the minor $\mathrm{T}$ allele of the ADP 276 possessed lower levels of HbA1c than subjects with the $\mathrm{G} / \mathrm{G}$ genotype $(3.58 \pm 0.10$ vs. $3.85 \pm 0.06 \%, \mathrm{p}<0.05)$. The presence of minor allele $\mathrm{A}$ in 
Table 6. The allele frequency of studied SNP in patients with anorexia nervosa, obesity and in a control group of healthy normal-weight women.

\begin{tabular}{lllll}
\hline & & $\begin{array}{l}\text { Control } \\
\text { group }\end{array}$ & $\begin{array}{l}\text { Anorexia } \\
\text { nervosa }\end{array}$ & $\begin{array}{l}\text { Obese } \\
\text { women }\end{array}$ \\
\hline \multirow{2}{*}{ RETN 62 } & Allele $G$ & $94 \%$ & $100 \%$ & $96 \%$ \\
& Allele $A$ & $6 \%$ & $0 \%$ & $4 \%$ \\
RETN -180 & Allele $C$ & $81 \%$ & $65 \%$ & $65 \%$ \\
& Allele $G$ & $19 \%$ & $35 \%$ & $35 \%$ \\
ADP 45 & Allele $T$ & $95 \%$ & $100 \%$ & $94 \%$ \\
& Allele $G$ & $5 \%$ & $0 \%$ & $6 \%$ \\
ADP 276 & Allele $G$ & $83 \%$ & $71 \%$ & $72 \%$ \\
& Allele $T$ & $17 \%$ & $29 \%$ & $28 \%$ \\
\hline
\end{tabular}

SNP RETN+62 showed lower levels of HbAlc compared to the $\mathrm{G} / \mathrm{G}$ genotype $(3.26 \pm 0.13$ vs. $3.80 \pm 0.05 \%$, $\mathrm{p}<0.001)$.

\section{Discussion}

The aim of our study was to determine the frequencies of $45 \mathrm{~T}>\mathrm{G}$ and $276 \mathrm{~T}>\mathrm{G}$ adiponectin and $62 \mathrm{G}>\mathrm{A}$ and $-180 \mathrm{C}>\mathrm{G}$ resistin gene polymorphisms in the patients with obesity, anorexia nervosa and a control group of healthy normal-weight women. Furthermore, we focused on the influence of particular genotypes on serum levels of adiponectin and resistin and on its influence on metabolic parameters including HOMA index as a rough measure of insulin sensitivity.

The presence of the minor $\mathrm{T}$ allele in the locus 276 of the adiponectin gene increased adiponectin levels in obese patients and decreased HbAlc concentrations in healthy women, respectively. These results are in accordance with previously published data. It has been described that subjects with the $\mathrm{G} / \mathrm{G}$ genotype in position 276 of the adiponectin gene had lower adiponectin concentrations and impaired glucose tolerance, respectively (Gonzalez-Sanchez et al. 2005, Hara et al. 2002). Carriers of the minor $T$ allele in position 276 of the adiponectin gene possessed higher adiponectin mRNA expression in visceral fat which positively correlated with adiponectin levels (Fredriksson et al. 2006). Interestingly, the presence of the minor $T$ allele of the position 276 in the adiponectin gene in anorexia nervosa patients was accompanied by increased cholesterol levels while no effect on glycated hemoglobin or circulating adiponectin levels was noted. Taken together our data suggest that the effect of the presence of the minor T allele in ADP 276 is significantly modified by nutritional status that can probably overcome some of modifying effects of this polymorphism on serum adiponectin levels.

Another polymorphism studied in our cohort of patients was $62 \mathrm{G}>\mathrm{A}$ polymorphism of resistin gene. Obese carriers of the minor A allele in the locus 62 of the resistin gene had significantly higher cholesterol levels than obese $\mathrm{G} / \mathrm{G}$ homozygotes, while the presence of the minor A allele in healthy normal-weight women was accompanied by lower HbA1c levels. Tan et al. (2003) found a lower frequency of allele A in this SNP in type 2 diabetic patients relative to non-diabetic subjects.

The association between the presence of the minor $G$ allele in position -180 of the resistin gene and higher BMI in anorexia nervosa patients has not been described yet. It is possible, that this SNP can be, as well as the presence of the minor T allele in SNP ADP +276 , the protective factor of some metabolic abnormalities.

With the exception of the above mentioned association between SNP $276 \mathrm{G}>\mathrm{T}$ of the adiponectin gene and serum adiponectin levels, no other influences of the studied polymorphisms on adiponectin or resistin levels were found in our study.

It has to be noted that our study is limited by relatively low number of subjects; therefore some minor genotype-induced differences in metabolic factors may have been missed due to lower statistical power. Despite this limitation our data together with previously published studies indicate that both adiponectin and resistin gene polymorphisms can significantly influence the metabolic phenotype of patients with nutritional disorders such as obesity and anorexia nervosa. We suggest that the manifestations of respective genotypes differ in patients with different nutritional status.

\section{Conflict of Interest}

There is no conflict of interest.

\section{Acknowledgements}

Supported by grant of Grant Agency of the Czech Republic 301/04/P167 and MZOVFN2005. 


\section{References}

ANDERLOVÁ K, KŘEMEN J, DOLEŽALOVÁ R, HOUSOVÁ J, HALUZÍKOVÁ D, KUNEŠOVÁ M, HALUZÍK M: The influence of very-low-calorie-diet on serum leptin, soluble leptin receptor, adiponectin and resistin levels in obese women. Physiol Res 55: 277-283, 2006.

ARITA Y, KIHARA S, OUCHI N, TAKAHASHI M, MAEDA K, MIYAGAWA J, HOTTA K, SHIMOMURA I, NAKAMURA T, MIYAOKA K, KURIYAMA H, NISHIDA M, YAMASHITA $S$, OKUBO $\mathrm{K}$, MATSUBARA K, MURAGUCHI M, OHMOTO Y, FUNAHASHI T, MATSUZAWA Y: Paradoxical decrease of an adipose-specific protein, adiponectin, in obesity. Biochem Biophys Res Commun 257: 79-83, 1999.

BERG AH, COMBS TP, DU X, BROWNLEE M, SCHERER PE: The adipocyte-secreted protein Acrp30 enhances hepatic insulin action. Nat Med 7: 947-953, 2001.

BRICHARD SM, DELPORTE ML, LAMBERT M: Adipocytokines in anorexia nervosa: a review focusing on leptin and adiponectin. Horm Metab Res 35: 337-342, 2003.

DEGAWA-YAMAUCHI M, BOVENKERK JE, JULIAR BE, WATSON W, KERR K, JONES R, ZHU Q, CONSIDINE RV: Serum resistin (FIZZ3) protein is increased in obese humans. $J$ Clin Endocrinol Metab 88: 5452-5455, 2003.

DELPORTE ML, BRICHARD SM, HERMANS MP, BEGUIN C, LAMBERT M: Hyperadiponectinaemia in anorexia nervosa. Clin Endocrinol (Oxf) 58: 22-29, 2003.

FILIPPI E, SENTINELLI F, TRISCHITTA V, ROMEO S, ARCA M, LEONETTI F, DI MARIO U, BARONI MG: Association of the human adiponectin gene and insulin resistance. Eur J Hum Genet 12: 199-205, 2004.

FREDRIKSSON J, CARLSSON E, ORHO-MELANDER M, GROOP L, RIDDERSTRALE M: A polymorphism in the adiponectin gene influences adiponectin expression levels in visceral fat in obese subjects. Int $J$ Obes (Lond) 30: 226-232, 2006.

GONZALEZ-SANCHEZ JL, ZABENA CA, MARTINEZ-LARRAD MT, FERNANDEZ-PEREZ C, PEREZ-BARBA M, LAAKSO M, SERRANO-RIOS M: An SNP in the adiponectin gene is associated with decreased serum adiponectin levels and risk for impaired glucose tolerance. Obes Res 13: 807-812, 2005.

GOUNI-BERTHOLD I, GIANNAKIDOU E, FAUST M, KRATZSCH J, BERTHOLD HK, KRONE W: Resistin gene 3 '-untranslated region $+62 \mathrm{G}->\mathrm{A}$ polymorphism is associated with hypertension but not diabetes mellitus type 2 in a German population. J Intern Med 258: 518-526, 2005.

HALUZíK M, HALUZÍKOVÁ D, BOUDOVÁ L, NEDVÍDKOVÁ J, BARÁČKOVÁ M, BRANDEJSKÝ P, NOVOTNÝ V, VILIKUS Z: The relationship of serum leptin levels and parameters of endurance training status in top sportsmen. Endocr Res 25: 357-369, 1999.

HALUZÍK M, COLOMBO C, GAVRILOVA O, CHUA S, WOLF N, CHEN M, STANNARD B, DIETZ KR, LE ROITH D, REITMAN ML: Genetic background (C57BL/6J versus FVB/N) strongly influences the severity of diabetes and insulin resistance in ob/ob mice. Endocrinology 145: 3258-3264, 2004a.

HALUZÍK M, PAŘÍZKOVÁ J, HALUZÍK MM: Adiponectin and its role in the obesity-induced insulin resistance and related complications. Physiol Res 53: 123-129, 2004b.

HARA K, BOUTIN P, MORI Y, TOBE K, DINA C, YASUDA K, YAMAUCHI T, OTABE S, OKADA T, ETO K, KADOWAKI H, HAGURA R, AKANUMA Y, YAZAKI Y, NAGAI R, TANIYAMA M, MATSUBARA K, YODA M, NAKANO Y, TOMITA M, KIMURA S, ITO C, FROGUEL P, KADOWAKI T: Genetic variation in the gene encoding adiponectin is associated with an increased risk of type 2 diabetes in the Japanese population. Diabetes 51: 536-540, 2002.

HAVEL PJ: Control of energy homeostasis and insulin action by adipocyte hormones: leptin, acylation stimulating protein, and adiponectin. Curr Opin Lipidol 13: 51-59, 2002.

HOTTA K, FUNAHASHI T, ARITA Y, TAKAHASHI M, MATSUDA M, OKAMOTO Y, IWAHASHI H, KURIYAMA H, OUCHI N, MAEDA K, NISHIDA M, KIHARA S, SAKAI N, NAKAJIMA T, HASEGAWA K, MURAGUCHI M, OHMOTO Y, NAKAMURA T, YAMASHITA S, HANAFUSA T, MATSUZAWA Y: Plasma concentrations of a novel, adipose-specific protein, adiponectin, in type 2 diabetic patients. Arterioscler Thromb Vasc Biol 20: 1595-1599, 2000. 
HOUSOVÁ J, ANDERLOVÁ K, KŘÍŽOVÁ J, HALUZÍKOVÁ D, KŘEMEN J, KUMŠTÝŘOVÁ T, PAPEŽOVÁ H, HALUZÍK M: Serum adiponectin and resistin concentrations in patients with restrictive and binge/purge form of anorexia nervosa and bulimia nervosa. J Clin Endocrinol Metab 90: 1366-1370, 2005.

KIM KH, LEE K, MOON YS, SUL HS: A cysteine-rich adipose tissue-specific secretory factor inhibits adipocyte differentiation. J Biol Chem 276: 11252-11256, 2001.

KUBOTA N, TERAUCHI Y, YAMAUCHI T, KUBOTA T, MOROI M, MATSUI J, ETO K, YAMASHITA T, KAMON J, SATOH H, YANO W, FROGUEL P, NAGAI R, KIMURA S, KADOWAKI T, NODA T: Disruption of adiponectin causes insulin resistance and neointimal formation. $J$ Biol Chem 277: 25863-25866, 2002.

LEE JH, CHAN JL, YIANNAKOURIS N, KONTOGIANNI M, ESTRADA E, SEIP R, ORLOVA C, MANTZOROS CS: Circulating resistin levels are not associated with obesity or insulin resistance in humans and are not regulated by fasting or leptin administration: cross-sectional and interventional studies in normal, insulinresistant, and diabetic subjects. J Clin Endocrinol Metab 88: 4848-4856, 2003.

MATTHEWS DR, HOSKER JP, RUDENSKI AS, NAYLOR BA, TREACHER DF, TURNER RC: Homeostasis model assessment: insulin resistance and beta-cell function from fasting plasma glucose and insulin concentrations in man. Diabetologia 28: 412-419, 1985.

MENZAGHI C, ERCOLINO T, DI PAOLA R, BERG AH, WARRAM JH, SCHERER PE, TRISCHITTA V, DORIA A: A haplotype at the adiponectin locus is associated with obesity and other features of the insulin resistance syndrome. Diabetes 51: 2306-2312, 2002.

RAJALA MW, OBICI S, SCHERER PE, ROSSETTI L: Adipose-derived resistin and gut-derived resistin-like molecule-beta selectively impair insulin action on glucose production. J Clin Invest 111: 225-230, 2003.

SCHERER PE, WILLIAMS S, FOGLIANO M, BALDINI G, LODISH HF: A novel serum protein similar to C1q, produced exclusively in adipocytes. $J$ Biol Chem 270: 26746-26749, 1995.

SMITH SR, BAI F, CHARBONNEAU C, JANDEROVA L, ARGYROPOULOS G: A promoter genotype and oxidative stress potentially link resistin to human insulin resistance. Diabetes 52: 1611-1608, 2003.

STEPPAN CM, BAILEY ST, BHAT S, BROWN EJ, BANERJEE RR, WRIGHT CM, PATEL HR, AHIMA RS, LAZAR MA: The hormone resistin links obesity to diabetes. Nature 409: 307-312, 2001.

TAN MS, CHANG SY, CHANG DM, TSAI JC, LEE YJ: Association of resistin gene 3'-untranslated region +62G-->A polymorphism with type 2 diabetes and hypertension in a Chinese population. J Clin Endocrinol Metab 88: 1258-1263, 2003.

XITA N, GEORGIOU I, TSATSOULIS A, KOURTIS A, KUKUVITIS A, PANIDIS D: A polymorphism in the resistin gene promoter is associated with body mass index in women with polycystic ovary syndrome. Fertil Steril 82: 1466-1467, 2004. 